\title{
Peran Konselor dalam Mengembangkan Karakter Siswa Peduli Sosial
}

\author{
Nila Frischa Panzola ${ }^{1 *}$, Yeni Karneli ${ }^{2}$ \\ Universitas Negeri Padang ${ }^{12}$ \\ *) Correspondence Author, e-mail: Nilafrischapanzola@gmail.com
}

\begin{abstract}
Abstrak: Di dalam pembuatan kepribadian/karakter pada siswa memerlukan sesuatu contoh yang nyata panutan dan contonya ialah seseorang guru BK. Seseorang guru BK wajib mempunyai keahlian dalam melayani siswa dan interaksi keduanya yang intensif lewat layanan yang diberikan hendak menjadikan siswa mencontoh kepribadian seseorang Guru BK. Oleh sebab itu, konselor sekolah wajib berpartisipasi aktif dalam pengembangan serta penumbuhan kepribadian pada siswa. Dalam Pembelajaran kepribadian ada sebagian kepribadian yang mau dibesarkan oleh pemerintah serta satuan Pembelajaran, antara lain kepribadian/karakter religious, kejujuran, toleransi, disiplin, kerja keras, kreatif, mandiri, demokratis, rasa mau ketahui, semangat kebangsaan, cinta tanah air, menghargai prestasi, bersahabat/ komunikatif, cinta damai, peduli social serta bertanggung jawab. Sehingga nantinya interaksi yang hendak dijalani tiap hari oleh siswa membentuk diri siswa yang berkarakter peduli sosial. Terpaut dengan aktivitas pembelajaran kepribadian/karakter di sekolah konselor sekolah harus memfasilitasi pengembangan serta penumbuhan kepribadian/karakter dan tanpa mengabaikan kemampuan hard skills lebih lanjut yang dibutuhkan dalam ekspedisi hidup pembuatan kepribadian/karakter di Sekolah. Mewujudkan seorang siswa merupakan wujud guru BK.
\end{abstract}

Kata kunci: Kedudukan Konselor, Kepribadian, Peduli Sosial

Article History: Received on 09/06/2020; Revised on 06/07/2020; Accepted on 11/08/2020; Published Online29/12/2020.

This is an open access article distributed under the Creative Commons Attribution License, which permits unrestricted use,
distribution, and reproduction in any medium, provided the orignal work is properly cited. O2020 by author.


Nilai moral sangat diperlukan oleh seluruh manusia mengingat nilai ialah landasan dari tingkah laku serta perbuatan manusia. ditinjau kalau moral sebagian anggota warga sudah rusak ataupun mulai merosot. Peristiwa yang terjadi menggambarkan kalau sikap membantu selaku wujud kepedulian sosial terhadap area terus menjadi luntur serta terkikis. Hasil riset yang dicoba Perwitasari( 2010) menampilkan penyusutan kepedulian sosial serta kepekaan pada anak muda terhadap orang lain serta lingkungannya. Anak muda lebih banyak mementingkan diri sendiri serta keberhasilannya tanpa banyak memikirkan kondisi orang lain di sekitarnya.

Perihal ini menimbulkan anak muda jadi terus menjadi individualis serta perilaku yang dipunyai terus menjadi pudar. Ali Nugraha serta Yeni P( 2006) dalam( Sugiyanto, tanpa tahun, 6) melaksanakan survey terhadap orang tua serta guru, kalau generasi saat ini lebih banyak mempunyai kesusahan emosi serta sosial dari pada generasi tadinya. Generasi saat ini lebih kesepian serta pemurung, lebih beringas, kurang mempunyai etika, gampang takut, gugup serta lebih implusif. Perkara tidak menyudahi disana, ketidaksesuaian antara das sein serta das sollenpun terjalin. Terjalin benturan sikap antara yang diterima di sekolah dengan di rumah ataupun kebalikannya sehingga pelajaran moral yang baru didapat diruang kelas tidak sangat berguna sebab tidak bisa dijadikan selaku kerutinan tiap hari.

Ki Hadjar Dewantara sudah jauh berpikir dalam permasalahan pembelajaran kepribadian lewat konsep Trilogi Pembelajaran yang dia kemukakan. Trilogi pembelajaran tersebut berisi atas 3 semboyan, ialah ing ngarsa sung tulada, ing madya mangun karsa serta tut wuri handayani. Tut wuri handayani berarti' dari balik seseorang guru wajib dapat membagikan dorongan serta arahan', ing madya mangun karsa maksudnya' di tengah murid, guru wajib menghasilkan prakarsa serta ilham' serta ing ngarsa sung tulada berarti' di depan, seseorang pendidik wajib berikan teladan ataupun contoh aksi yang baik'.

Telah waktunya guru- guru meninggalkan tata cara lama mengajar yang cuma semata- mata melakukan tuntutan tugas serta mengejar sasaran kurikulum semata, sehingga tidak mempunyai idealisme jadi seseorang pendidik. Guru dituntut buat kembali jadi semacam yang Ki Hajar Dewantara katakan, ialah seseorang yang ing ngarso sing tulodo, ing madyo mangun karso serta tut wuri handayani. Guru yang bukan cuma mengajar, tetapi pula mendidik.

Aktualisasi ajaran Ki Hajar Dewantara di masa globalisasi ini bermanfaat buat membangun kepribadian bangsa. Pembelajaran kepribadian ini hendak melepaskan Indonesia dari predikat negeri terkorup, birokrasi terburuk serta lain- lain, di mana seluruhnya itu diakibatkan oleh lemahnya sistem pembelajaran yang berkarakter budaya Indonesia. Butuh langkah bersama buat mewujudkannya, sehingga Indonesia berganti jadi bangsa berkarakter besar.

Dunia Pembelajaran wajib membagikan masukan tentang sikap- sikap hirau serta nilai- nilai moral yang butuh dibesarkan. Bagi Rukiyati, dkk( 2008: 59) melaporkan nilai untuk manusia dipakai serta dibutuhkan buat jadi landasan alibi, motivasi dalam seluruh perilaku, tingkah laku serta perbuatannya. Nilai ialah suatu yang dihargai, dijunjung besar, yang memberi warna serta menjiwai aksi manusia. 
Konselor diharapkan sanggup menanggulangi seluruh permasalahan tersebut serta disebabkan konselor bertabiat cair yang sanggup mengisi seluruh segi kehidupan siswa hingga konselorlah yang hendak jadi percontohan ataupun model tokoh tempat acuan mereka dalam menuntaskan permasalahan serta tempat para siswa berkeluh kesah. Fakta secara empiris menampilkan masih banyak siswa yang belum dapat berperilaku secara normatif, antara lain mulai dari berperilaku tidak sopan, berbohong( tercantum membolos), membuat onar, berkelahi, hingga dengan berperilaku melanggar norma kesusilaan. Perihal ini terjalin antara lain dari sisi kedudukan yang semestinya dicoba oleh seseorang konselor sekolah dalam pengembangan aspek individu serta sosial siswa yang belum optimal. Meski konselor sekolah bukan selaku salah satunya pihak yang wajib ataupun sangat bertanggung jawab terhadap keadaan tersebut, tetapi konselor sekolah tidak dapat lepas dari tanggung jawab tersebut. Dari perspektif ini diharapkan bisa membagikan wacana buat mengurai kerumitan permasalahan kedudukan yang wajib ditampilakn oleh konselor sekolah.

\section{MeTODE}

Metode penelitian yang digunakan dalam penelitian ini adalah metode studi kepustakaan atau library research. Penelitian kepustakaan adalah teknik pengumpulan data dengan mengadakan studi penelaahan terhadap buku-buku, literatur-literatur, catatan-catatan dan laporan-laporan yang ada hubungannya dengan masalah yang dipecahkan (Nazir,2003).

\section{Pembahasan}

Pendidikan karakter merupakan sesuatu sistem penamaan nilai- nilai karakter yang meliputi komponen pengetahuan, pemahaman ataupun keinginan, serta aksi buat melakukan nilai- nilai tersebut, baik terhadap Tuhan Yang Maha Esa, diri sendiri, sesama, area, ataupun kebangsaan. Pengembangan karakter bangsa bisa dicoba lewat pertumbuhan karakter seseorang. Hendak namun, sebab manusia hidup dalam lingkungan sosial serta budaya tertentu, hingga pertumbuhan kepribadian orang seorang cuma bisa dicoba dalam lingkungan sosial serta budaya yang bersangkutan. Maksudnya, pertumbuhan budaya serta karakter bisa dicoba dalam sesuatu proses pembelajaran yang tidak membebaskan partisipan didik dari lingkungan sosial, budaya warga, serta budaya bangsa.

Noor( 2010: 52- 53)“ Pendidikan karakter sebetulnya mempunyai urgenitas yang sangat besar dalam membangun moral anak bangsa. Oleh sebab itu telah sepatutnya pembinaan karakter tercantum dalam modul yang wajib diajarkan serta dipahami dan direalisasikan oleh peserta didik dalam kehidupan tiap hari. Dikala ini di seluruh jenjang pembelajaran mulai diterapkan pembelajaran kepribadian yang ialah satu kesatuan program kurikulum satuan pembelajaran sehingga secara dokumen diintegrasikan ke dalam Kurikulum Tingkatan Satuan Pembelajaran( KTSP) mulai dari visi, misi, tujuan, struktur serta muatan kurikulum, kalender pembelajaran, silabus, rencana penerapan pembelajaran( RPP)( Kemdiknas, 2011: 9). 


\section{Tujuan Pendidikan Karakter}

Pendidikan karakter bertujuan buat tingkatkan kualitas penyelenggaraan serta hasil pembelajaran di sekolah yang menuju pada pencapaian pembuatan karakter serta akhlak mulia partisipan didik secara utuh, terpadu, serta balance, cocok standar kompetensi lulusan. Lewat pembelajaran kepribadian diharapkan partisipan didik sanggup secara mandiri tingkatkan serta memakai pengetahuan, mengkaji serta menginternalisasi dan mempersonalisasi nilai- nilai karakter serta akhlak mulia sehingga terwujud dalam sikap tiap hari( Suyanto, 2010: 3).

Karakter dibesarkan lewat sesi pengetahuan( knowing), penerapan( acting), serta kerutinan( habit). Dengan demikian, dibutuhkan 3 komponen kepribadian yang baik( components of good character), ialah moral knowing( pengetahuan tentang moral), moral feeling ataupun perasaan( penguatan emosi) tentang moral, serta moral action ataupun perbuatan bermoral. Dimensi- dimensi yang tercantum dalam moral knowing yang hendak mengisi ranah kognitif merupakan pemahaman moral( moral awareness), pengetahuan tentang nilai- nilai moral( knowing moral values), penentuan sudut pandang( perspective taking), logika moral(moral reasoning), keberanian mengambil perilaku( decision making), serta pengenalan diri( self knowledge). Moral feeling ialah penguatan aspek emosi partisipan didik buat jadi manusia berkarakter. Penguatan ini berkaitan dengan bentuk- bentuk perilaku yang wajib dialami oleh partisipan didik, ialah pemahaman hendak jati diri( conscience), yakin diri( self esteem), kepekaan terhadap derita orang lain( emphaty), cinta kebenaran( loving the good), pengendalian diri( self control), kerendahan hati( humility). Moral action ialah perbuatan ataupun aksi moral yang ialah hasil( outcome) dari 2 komponen kepribadian yang lain.

Dalam menguasai apa yang mendesak seorang dalam perbuatan yang baik( act morally) hingga wajib dilihat 3 aspek lain dari kepribadian, ialah kompetensi( competence), kemauan( will), serta kerutinan( habit). Tahapan ini sejalan dengan komentar Lickona( 2014: 74) yang mengemukakan kalau komponen- komponen kepribadian yang baik terdiri dari 3 bagian yang silih terpaut, ialah pengetahuan tentang moral( moral knowing), perasaan moral( moral feeling), serta aksi moral( moral behavior). Dalam kaitan itu, kepribadian yang baik bermula dari mengenali kebaikan, menyayangi ataupun menginginkan kebaikan, serta kesimpulannya dengan tekad yang serius orang berjuang buat melaksanakan kebaikan.

\section{Materi Pendidikan Karakter di Dalam Layanan Bimbingan}

Modul Pendidikan Karakter dalam Layanan Tutorial, antara lain bisa mencakup ialah sikap, pengetahuan tentang karakter, uraian tentang moral sosial, keahlian pemecahan permasalahan, kompetensi emosional, hubungan dengan orang lain, perasaan keterikatan dengan sekolah, prestasi akademis, kompetensi berbicara serta Sikap kepada guru( Berkowitz, Battistich, dan Bier dalam Muhammad Nur Wangid, 2010). Kemudian terdapat pula nilai- nilai dalam Pendidikan karakter Bangsa ialah religius, jujur, toleransi, disiplin, kerja Keras, kreatif, mandiri, demokratis, rasa mau ketahui, semangat kebangsaan, cinta tanah air, menghargai Prestasi, bersahabat/ Komuniktif, cinta Damai, hirau area, hirau sosial, serta tanggung- jawab. Pendidikan karakter yang diintegrasikan ke dalam segala warga sekolah selaku sesuatu strategi buat menolong menegaskan kembali siswa buat berhubungan dengan konflik, 
melindungi siswa buat senantiasa senantiasa siaga dalam area Pembelajaran, serta menginvestasikan kembali warga buat berpartisipasi aktif selaku masyarakat negeri.

Dalam perihal ini, perihal yang sangat dibahas merupakan karakter kepedulian. Dimana masayarakat telah mulai melupakan perihal tersebut serta para orang tua juga telah mengabaikan karakter kepedulian dari sang anak. Sehingga banyak anak yang pula mengabaikan kepribadian kepedulian tersebut akibat dari pertumbuhan era. Sehingga karakter kepedulian sangat berarti buat dibahas memandang tatanan kehidupan manusia yang telah mulai mengabaikan karakter kepedulian.

\section{Peduli Sosial Salah Satu Pendidikan Karakter}

Kasus peduli sosial digolongan partisipan peserta didik ialah kasus yang butuh diatasi oleh segala golongan, tercantum didalamnya institusi pembelajaran ialah sekolah( Ginanjar, 2017: 119). Sekolah jadi lembaga yang melakukan pendidikan karakter. Salah satu nilai yang wajib diterapkan ialah nilai kepedulian sosial. Karakter peduli sosial merupakan perilaku serta aksi yang senantiasa mau berikan dorongan pada orang lain serta mayarakat yang memerlukan( Daryanto, 2013: 71). Nilai- nilai pembelajaran karakter peduli sosial tercantum dalam peraturan Presiden Republik Indonesia no 87

Tahun 2017 pasal 3 yang berisi Penguatan pendidikan karakter dilaksanakan dengan mempraktikkan nilai- nilai pancasila dalam pembelajaran kepribadian paling utama meliputi nilai- nilai religius, jujur, toleran, disiplin, bekerja keras, kreatif, mandiri, demokratis, rasa mau ketahui, semangat kebangsaan, cinta tanah air, menghargai prestasi, komunikatif, cinta damai, gemar membaca, hirau area, hirau sosial, bertanggung jawab.

Pada Kurikulum ini mempraktikkan karakter pada partisipan peserta didik serta diimplementasikan lewat proses pendidikan. Nilai- nilai karakter yang disisipkan dalam pendidikan cocok dengan Pancasila, Undang-Undang Dasar 1945 yang kembangkan lewat bermacam peraturan peundang- undangan serta di breakdown lewat Visi serta Misi sekolah sehingga ada bermacam program pendidikan yang menunjang penguatan pembelajaran karakter( PPK). peduli pada sahabat dapat dilihat dari apa yang dicoba oleh siswa antara lain menjenguk sahabat kala sakit, menolong sahabat yang lagi hadapi kesulitan, ataupun membantu sahabat yang lagi terserang musibah alam. Perilaku inilah yang hendak dibentuk di dalam diri partisipan didik di sekolah yang diharapkan bisa menghapuskan pergaulan yang senantiasa pilih- seleksi.

\section{Peran Konselor dalam Mengembangkan Karakter Peduli Sosial Dalam Kegiatan Pembelajaran di Kelas}

Pelaksanaan pendidikan karakter pula diharapkan tidak hendak terlepas dari pelayanan BK di sekolah. Pelayanan BK di sekolah ialah salah satu layanan yang pula bisa membagikan pergantian pada pertumbuhan serta keahlian partisipan didik, baik dalam proses belajar mengajar, religius, sosial, serta karir dari partisipan didik itu sendiri. Implementasi pendidikan karakter malalui pelayanan BK di sekolah, diharapkan sanggup buat tingkatkan nilai- nilai kepribadian yang terdapat pada partisipan didik/ siswa. Sebab dalam pelayanan BK itu sendiri telah menekankan pada 4 bidang layanan, ialah individu, sosial, belajar serta karir. Sebaliknya dalam pembelajaran kepribadian pula lebih memencet kan pada nilai- nilai. Pembelajaran kepribadian jauh lebih bisa jadi 
buat bekerja kala itu dirancang dengan baik, kala perihal itu tergantung pada prinsipprinsip berbasis riset serta kerangka konseptual bermakna, serta kala itu seluruhnya serta akurat dilaksanakan.

Penyelenggaraan pendidikan karakter banyak membutuhkan pendekatan personal, baik dalam makna guru pembimbing wajib kompeten serta layak buat dicontoh, disamping itu pula pada biasanya para siswa hendak' respek' kepada mereka yang mempunyai keakraban secara individu sehingga mempermudah terbentuknya penyampaian pesan- pesan ataupun data tentang pendidikan karakter. Terdapat banyak aspek pemicu terbentuknya kesalahan anggapan tentang konselor sekolah tersebut di atas, salah satunya kinerja konselor sekolah yang belum optimal ataupun belum dapat menampilkan tugas serta kedudukan yang sepatutnya dikerjakan selaku seseorang konselor( Sumantri, E. 2010).

Perihal itu sebab konselor sekolah yang memanglah secara spesial mempunyai tugas buat menolong siswa meningkatkan kepedulian sosial serta masalah- masalah kesehatan mental, dengan demikian konselor sekolah wajib sangat akrab dengan program pembelajaran kepribadian. Berartinya kedudukan konselor sekolah dalam pembelajaran kepribadian ini American School Counselor Association( ASCA) menampilkan dukungannya dengan melaporkan:" Professional school counselors need to take an active role in initiating, facilitating and promoting character education programs in the school curriculum. The professional school counselor, as a part of the school community and as a highly resourceful person, takes an active role by working cooperatively with the teachers and administration in providing character education in the schools as an integral part of the school curriculum and activities"( ASCA, 1998).

Dengan demikian, statment di atas menyiratkan perlunya konselor sekolah buat tetap diperingatkan supaya mereka menguasai serta menyadari salah satum tugas pokoknya. Perihal itu tidak dapat dihindarkan sebab hasil riset menampilkan kalau sesungguhnya program tutorial serta konseling di sekolah pada dasarnya pula telah mengakomodasi modul tugas tersebut( Ryan,\&amp; Bohlin, 2000). Tetapi demikian, terdapat sebagian komentar melaporkan kebalikannya konselor sekolah sebaiknya menghindari pendidikan karakter sebab terasa berlawanan dengan kebebasan akademis, ataupun apalagi menyalahi ataupun menyangkut kepercayaan individu ataupun melanggar hak serta sikap individu( Ryan,\&amp; Bohlin, 2000).

Butuh dicermati serta dipertimbangakan oleh konselor sekolah kalau seluruh wujud pembelajaran tentu berisi modul tentang yang mengarahkan nilai- nilai kebaikan, kemanusiaan, serta kehidupan yang pada hakekatnya itu seluruh merupakan pembelajaran kepribadian. Terpaut dengan aktivitas pendidikan karakter di sekolah konselor sekolah harus memfasilitasi pengembangan serta penumbuhan karakter dan tanpa mengabaikan kemampuan hard skills lebih lanjut yang dibutuhkan dalam ekspedisi hidup dan dalam mempersiapkan karier( Kementerian Pembelajaran Nasional, 2007: 186).

Oleh sebab itu, konselor sekolah wajib berpartisipasi aktif dalam pengembangan serta penumbuhan karakter pada siswa. Metode konselor dalam menanamkan karakter kepedulian social dengan metode konselor membagikan uraian yang dapat berbentuk cerita, motivasi ataupun lewat contoh aktivitas tiap hari terlebih 
dulu kepada siswa, sehabis siswa paham dengan apa yang sudah di informasikan. Siswa dimohon buat mempraktikkan apa yang di informasikan.

Serta pula konselor dapat membagikan program aktivitas yang dapat dicoba siswa secara mandiri yang terancang dalam program tutorial serta konseling, serta pula bersama- sama dengan pendidik lain( guru bidang riset misalnya) yang terancang dalam program sekolah yang dicoba secara sinergis dari sebagian pihak. Metode penanaman karakter tersebut pula diperkuat dengan riset yang dicoba( Taufik 2014: 6364) hasil penilitian membuktikan kalau dalam penanaman karakter bisa dicoba dengan metode selaku berikut: a). Uraian: siswa diajarkan buat memhami iktikad serta tujuan dari nilai- nilai kepribadian yang dipelajari. b). Penggulangan ataupun pembiasaan: guru menyesuikan siswa buat mempraktikkan nilai- nilai tertentu bersumber pada konvensi yang terbuat. Misalnya mempraktikkan kepedulian sosial dalam perihal berbagi. c). Keteladanan: guru selaku contoh dalam keteladanan siswa. Keteladanan yang ditunjukkan guru berakibat positif untuk penguatan penanaman nilai- nilai positif pada siswa.

Serta dalam penanaman pendidikan karakter kepedulian sosial tidak hanya konselor yang membentuk karakter, orang tua juga pula wajib berfungsi dalam pembuatan karakter anak. Jadi, antara konselor dengan orang tua wajib berkolaborasi dalam pembuatan karakter anak. Salahudin serta Alkrienciehie (2013: 31) kita wajib bersama- sama berikhtiar membentuk kepribadian bangsa lewat Pembelajaran karakter. Pembelajaran pendidikan karakter yang diartikan merupakan Pembelajaran unt uk kalangan pelajar, siswa serta warga universal. Para terpelajar memiliki tanggung jawab moral buat menata kembali kepribadian bangsa yang lemah jadi kokoh dengan menampilkan kepribadian unggul serta karakter kepemimpinan. Namun pada kenyataanya orang tua mayoritas menyerahkan Pembelajaran karakter anak kepada sekolah, sehingga kurang mencermati karakter anak dirumah, sementara itu kepribadian anak pula berarti buat kehidupan masa depan anak semacam kepribadian kepedulian sosial. Riset dari Dewayanie( 2014) menunjang hasil riset ini ialah orang tua wali serta konselor wajib jadi sesuatu pedoman tercapai serta tidaknya penanaman pembuatan karakter baik yang di idamkan tercapai.

Peranan konselor dalam pembuatan karakter siswa ialah konselor berfungsi selaku pendidik, menanamkan akhlak baik, membagikan pengajaran yang relevan lewat cerita, serta berlagak hangat dengan partisipan didik.

\section{KESIMPULAN}

"Karakter" berarti sifat- sifat kejiwaan, akhlak ataupun budi pekerti yang membedakan seorang dari yang lain: tabiat, sifat Dalam Pendidikan karakter ada sebagian karakter yang mau dibesarkan oleh pemerintah serta satuan Pembelajaran, antara lain karakter religious, kejujuran, toleransi, disiplin, kerja keras, kreatif, mandiri, demokratis, rasa mau ketahui, semangat kebangsaan, cinta tanah air, menghargai prestasi, bersahabat/ komunikatif, cinta damai, gemar membaca, hirau hendak area, hirau social serta bertanggung jawab. Sehingga bisa berakibat Positif serta Negatif dalam Berlagak Hirau Sosial Kepedulian sosial ialah akhlak terpuji yang wajib senantiasa dihidup suburkan dalam jiwa tiap orang. Kepedulian seorang mempunyai akibat positif 
dalam kehidupan bermasyarakatyang melaporkan kalau partisipan didik sangat bergantung serta memerlukan dorongan orang lain yang mempunyai kewibawaan serta kedewasan. Dari komentar tersebut telah jelas kalau guru membagikan kedudukan yang sangat berarti dalam meningkatkan Pembelajaran kepribadian pada diri siswa.

Metode konselor dalam menanamkan karakter kepedulian social dengan metode konselor membagikan uraian yang dapat berbentuk cerita, motivasi ataupun lewat contoh aktivitas tiap hari terlebih dulu kepada siswa, sehabis siswa paham dengan apa yang sudah di informasikan. Siswa dimohon buat mempraktikkan apa yang di informasikan. Serta pula konselor dapat membagikan program aktivitas yang dapat dicoba siswa secara mandiri yang terancang dalam program tutorial serta konseling, serta pula bersamasama dengan pendidik lain( guru bidang riset misalnya) yang terancang dalam program sekolah yang dicoba secara sinergis dari sebagian pihak.

\section{REFERENSI TERBUKA.}

American School Counseling Association. 1998. American School Counseling Association's Position Statement On CharacterEducation. Http:-//Www.Schoolcounselor.Org/Content.Cfm?L1=1000\&L2=7.

Daryanto. 2013. Implementasi Pendidikan Karakter Di Sekolah. Yogyakarta: Grava Media. Dawayanie, Dwi Rangga Vischa. 2014. “Kerjasama Orang Tua Dan Sekolah Dalam Pembentukan Karakter Siswa Sdit Salsabila 3 Banguntapan". Unniversitas Islam Negri Sunan Kalijaga Yogyakarta.

Dewantara, K. H. 1962. Pendidikan. Jogjakarta: Taman Siswa. Eric Resource Center Ed475389 2003-06-00 Character Education: What Counselor Educators Need To Know. Eric/Cass Digest. Www.Eric.Ed.Gov. (Diunduh 28 Februari 2021).

Ginanjar, A. 2017. "Penguatan Peran Ips Dalam Meningkatkan Keterampilan Sosial Peserta Didik". Jurnal Harmony, 1 (1). Semarang: Fis Unnes.

Kemdiknas. 2011. Panduan Pelaksanaan Pendidikan Karakter. Jakarta.

Lickona, Thomas. 2014. Pendidikan Karakter, Panduan Lengkap Mendidik Siswa Menjadi Pintar Dan Baik.Bandung: Nusa Media.

Rukiyati. 2008. Pendidikan Pancasila. Yogyakarta: Uny Press.

Ryan, K. \& Bohlin, K. 2000. Teacher Education's Empty Suit. Education Week On The Web. Http://Www.- Edweek.Org/Ew/Ewstory.Cfm?Slug =26ryan.H19

Salahudin, Anas Dan Irwanto Alkrienciehie. 2013. Pendidikan Karakter Pendidikan Berbasis Agama Dan Budaya Bangsa. Bandung : Pustaka Setia.

Sumantri, E. (2010). Pendidikan Karakter Harapan Handal Bagi Masa Depan PendidikanBangsa. Kuliah Umum Prodi Pendidikan Umum Sps Upi.

Suyanto. 2010. Panduan Pendidikan Karakter Di Sekolah Menengah Pertama. Jakarta: Direktorat Pembinaan Smp, Ditjenmandikdasmen.

Suyanto. Urgensi Pendidikan Karakter. Tersedia Di Http://Waskitamandiribk. Wordpress.Com/2010/06/02/Urgensi-Pendidikan- Karakter/.)

Taufik. 2014. Pendidikan Karakter Disekolah: Pemahaman, Metode Penerapan Dan Peranan Tiga Elemen. Jurnal Ilmu Pendidikan. Vol.20. 63-64. 